\title{
Comparison of Age-Related anti Müllerian Hormone, Inhibin-b Levels and Follicle Reserve in Rat Ovarium
}

\author{
Comparación de la Hormona Anti-Mülleriana Relacionada con la Edad, \\ los Niveles de Inhibina-b y la Reserva Folicular en el Ovario de Rata
}

\author{
Gizem Söyler'; Güler Bugdayci² \& Aysel Kükner³
}

\begin{abstract}
SÖYLER, G.; BUGDAYCI, G. \& KÜKNER, A. Comparison of age-related anti müllerian hormone, inhibin-b levels and follicle reserve in rat ovarium. Int. J. Morphol., 39(4):1074-1080, 2021.

SUMMARY: Anti-Müllerian hormone (AMH) and Inhibin B (INHB) in the glycoprotein structure are members of the transforming growth factor $\beta$ family and expressed by granulosa cells from puberty. AMH is a factor that increases the life span of small developing follicles. For this reason, it is widely used to determine the ovarian reserve and age. Inhibin-B secreted from granulosa cells plays a role in regulation of the Follicle Stimulating Factor (FSH) and determination of the follicle diameter. There are few studies on the effect of these two age-related hormones on ovarian histology in rats. In this study, AMH and INHB expression in ovarian tissues of female rats of different age groups, their relationship with ovarian structure and folliculogenesis were examined histologically and biochemically. Wistar Albino rats were used in the study and a total of 3 groups were formed. The ovaries of rats in the pre-oestrous period were collected, and follicle count was performed on tissue sections in batches. Expression of AMH in the follicles was identified immunohistochemically. In serum, AMH and INHB levels were assessed by ELISA method and their significance was evaluated statistically. Results from light microscopic examination determined that AMH was expressed from the granulosa cells of developing follicles. INHB expression during the prepubertal period and $\mathrm{AMH}$ had a protective effect on the ovarian reserve and the number of developing follicles, respectively.
\end{abstract}

KEY WORDS: Rat; Age; Ovary; Anti-Müllerian hormone; Inhibin B.

\section{INTRODUCTION}

Females begin to develop a certain number of follicles in each menstrual cycle, one of which develops into a mature follicle. Oogenesis is regulated by various hormones secreted in the body. Within the network of hormonal interactions, follicle development is examined in two sections as gonadotropin dependent and gonadotropin independent (Cossigny et al., 2012). FSH stimulates the development of follicles in ovaries of an individual reaching puberty (Eppig, 2001). Granulosa cells are responsible for the development of oocyte and are in charge of synthesizing oestradiol, progesterone, inhibin-B (INHB) and Anti-Müllerian Hormones (AMH). The level of these hormones indicates the developing follicle population. (Matsuda et al., 2012). $\mathrm{AMH}$ has a dimeric glycoprotein structure and is secreted from the primary follicles since the beginning of puberty. No significant difference is observed in the serum AMH levels during the menstrual cycle; however when evaluated based on age, it is observed that expression reaches the highest level in puberty and AMH levels becomes unmeasurable since menopause (Nelson et al., 2012; Grynnerup et al., 2012). In follicular fluid, unlike serum, AMH expression increases in granulosa cells as the aging commences (Kedem et al., 2014). Three events are revealed by $\mathrm{AMH}$ expression; first, AMH expression creates an autocrine effect in granulosa cells, then binds to type II receptors located on the cells and activates Smad proteins in the cell, leading to gene expression. As a result, the granulosa cells proliferate, allowing the follicle to grow (Knight \& Glister, 2006). Second, AMH stops the development of primordial follicles by suppressing FSH. This event protects the primordial follicle pool and prevents early menopause (Visser \& Themmen, 2005). Finally, the aromatase synthesis required for the expression of oestradiol, one of the FSHdependent oestrogen types, is reduced by AMH, which prevents all cells from ovulating by reducing the Luteinizing Hormone (LH) receptor expression. As a result, a single oocyte susceptible to FSH continues to develop and the dominant follicle is selected. Since AMH is a factor that 
increases the life span of small developing follicles, it is widely used to determine the age and reservoir of the ovary (Visser et al., 2007; Kedem et al.). Inhibins, other peptide member of the transforming growth factor b superfamily, are heterodimeric glycoproteins (Woodruff \& Mather, 1995). Inhibin A and inhibin B are proteins that are involved in the regulation of reproductive system (DePaolo et al., 1991). Inhibin B (INHB) is involved with ovarian steroids and ovarian protein hormones in the occurrence of ovulation and formation of a new cycle in the absence of fertilization within the female reproductive system interactions, in gonadotropin fluctuations (Ackland et al., 1990). INHB is a hormone specific to granulosa cells and is secreted from developing unstimulated preovulatory follicles, preantral and small antral follicles. Therefore, the circulating INHB levels generally indicates the synthesis of follicles. Thus, INHB also acts as a marker showing the number of developing small antral follicles. The decrease in INHB levels is the earliest marker, indicating the declining follicle numbers in the reproductive period (Welt, 2004). The INHB levels in follicle fluid is determined to be related to follicle diameters in folliculogenesis; $10-12 \mathrm{~mm}$ diameter follicles have the highest concentration of INHB and are measured to be 1000 times more in follicular fluid than in circulation; where in follicles less than 6-7 $\mathrm{mm}$ in diameter, the INHB levels are at much lower concentrations (Welt et al., 1999). In the literature review, histological studies in rats are few in numbers. In this study, it was aimed to investigate the age-related structural changes in ovaries, AMH expression in follicles, AMH, INHB and FSH levels in serum and their interactions with each other and ovarian reserve of the female rats.

\section{MATERIAL AND METHOD}

This study was conducted in strict accordance with the recommendations of the National Institutes of Health's Guide for the Care and Use of Laboratory Animals. The research protocol with animal experimentation was approved by the Scientific Ethics Committee of University Abant Izzet Baysal (Protocol Number: 2016/05).

A total of 36 Wistar Albino rats were used in the study, and a total of 3 period groups were formed: prepubertal (1 month), reproductive (2-8 months) and premenopausemenopause (17-24 months). The animals were fed with standard pellets and tap water as ad libitum. Vaginal smears were taken to determine the oestrus cycles of the subjects and period groups were determined under the light microscope, with the observation of variances and density of the cells. The ovarian tissues samples from the subjects were stained with hematoxylin-eosin. Primarily, polyclonal goat anti-anti-
Müllerian hormone for AMH staining (Santa Cruz sc-6886, 1: 100); Secondarily, the Thermo Scientific UltraVision Large Volume Detection System Anti-Polyvalent was performed by applying HRP (Ref. No.: TP-060-HL) as specified in the data sheets.

Microscopic Evaluation and Follicle Count. 10 batch sections of each subject with hematoxylin eosin staining were examined under light microscopy and follicle count was performed. All follicles that distinctly detected in the ovarian tissue, from Tunica albuginea to the medulla, were classified, as primordial and developing, and counted. First, the follicles in each section was determined, then the follicle numbers of a single ovary were collected, and the number of follicles in each ovary was determined as a mean value. Follicles with and without $\mathrm{AMH}$ immune staining were evaluated in individuals of each group. Follicle cells that stained as AMH positive and their stain intensity was determined. Follicle counting process was performed using 200x (20x objective and 10x lens) magnification.

Biochemical Assessment. AMH, INHB and FSH levels were detected with biochemical tests and assessed. EnzymeLinked Immunosorbent Assay (ELISA) method was used for hormone measurements. Reference value ranges were accepted as 0.156-10 ng / mL for AMH (kit Elabscience EEL-R0640), 3.125-200 ng / mL for FSH (kit Elabscience EEL-R0391), and 15.625-1000 pg/ mL for INHB (kit Elabscience E-EL-R1027). BioRad ELISA reader was used as a bio detection tool.

Statistical Assessment. SPSS 17.0 package program was used for statistical analysis of the data. First, the average and median values and standard deviations of the groups were calculated. The parameter distribution between groups is determined by Kruskal Wallis Test. Mann-Whitney U Test was performed to evaluate the correlation between each group. Comparisons between parameters were calculated with Spearman Two Tail Test. Statistical significance value was taken as $\mathrm{p}$ value $<0.05$.

\section{RESULTS}

Biochemical Results. It was observed that the serum levels of $\mathrm{AMH}$ and inhibin B were lower in the prepubertal period compared to other periods, where increased in the active reproductive period and decreased in the premenopausalmenopausal period. It was found that there was a positive correlation between serum inhibin B level and FSH level, and no significance correlation was realised between the other hormone (Fig. 1). 


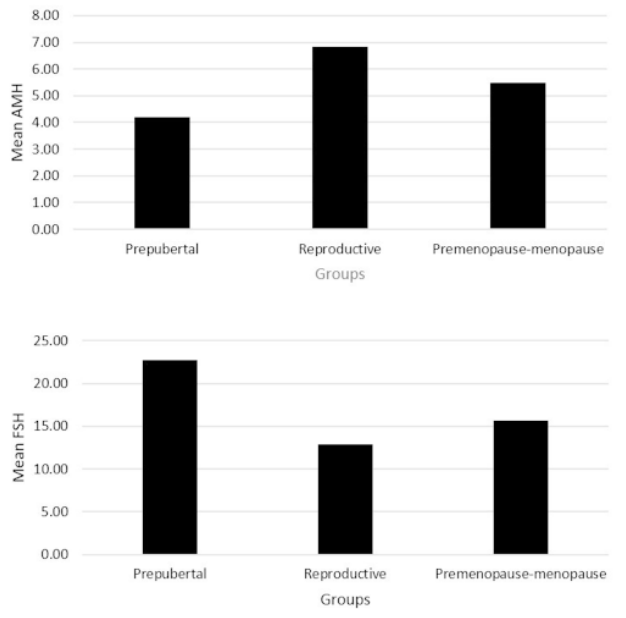

Histological Results. In the subjects at premenopausalmenopausal period, a low amount of developing follicle was observed in comparison to other groups. There was a significant difference between primordial and developing follicle numbers depending on the age (0.002 and 0.002, respectively), and a decrease was observed in both agerelated parameters (Fig. 2). A significant correlation was detected between the prepubertal period and the premenopause-menopause period, and between the active reproductive period and the premenopause-menopause period in both primordial and developing follicle numbers. In light microscopic evaluation and follicle count of the rat ovaries, it was observed that the ovarian volume and vascularity increased in relation with the age and luteal cells were abundant in the cortex stroma.

In the prepubertal period, increased number of follicles developed compared to other groups (Fig. 3). In immunohistochemical assessment, AMH expression was not observed in primordial follicles in any of the groups. AMH expression was observed in the developing (primary,

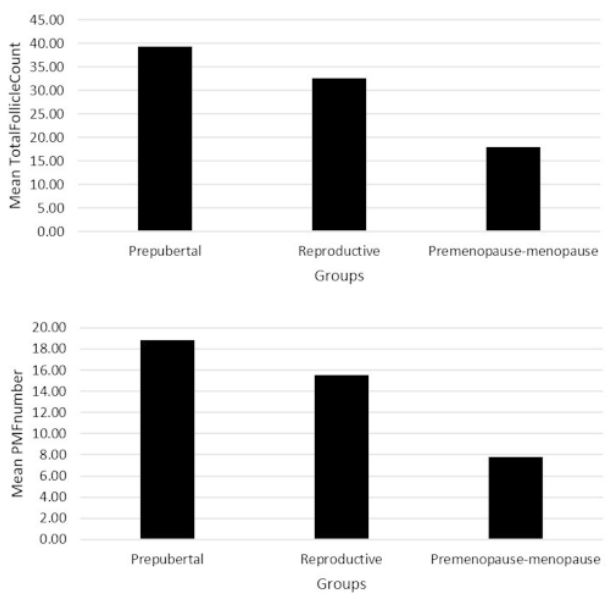

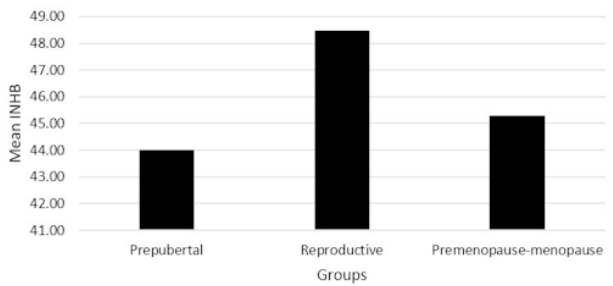

Fig. 1. Blood serum AHM, INHB and FSH levels are indicated for each group.

preantral, secondary and tertiary) follicles. When the follicles were evaluated according to age, there was no difference in expression between follicles of the same type. It was observed that there was a decrease in the number of AMH secreting cells in secondary follicles and tertiary follicles during the late period, and only a low expression of AMH was detected in mural granulose and cumulus cells in tertiary follicles. AMH expression was not observed in atretic follicles, theca interna and theca externa cells (Fig. 4).

In comparison of serum AMH levels and follicle count data, no correlation of statistical significance was observed between the AMH levels and number of primordial follicles, whereas a negative correlation was observed between the number of follicles developing in the prepubertal period and serum AMH levels ( $\mathrm{p}$ value $=0.036$ ).

When serum INHB levels and follicle count are compared, there was no correlation between the INHB levels and developing follicle count. A statistically positive correlation was observed between the primordial follicle count and serum INHB levels in the prepubertal period ( $p$ value $=0.42$ ).

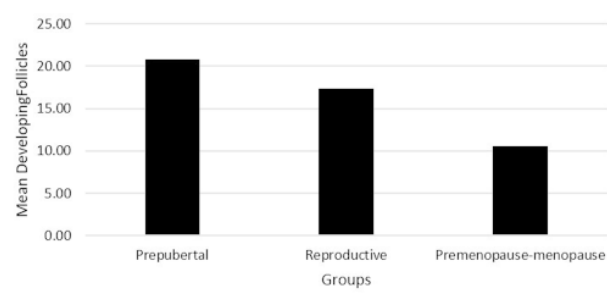

Fig. 2. Total follicle numbers, developing follicle numbers and primordial follicle numbers are indicated for each group. 

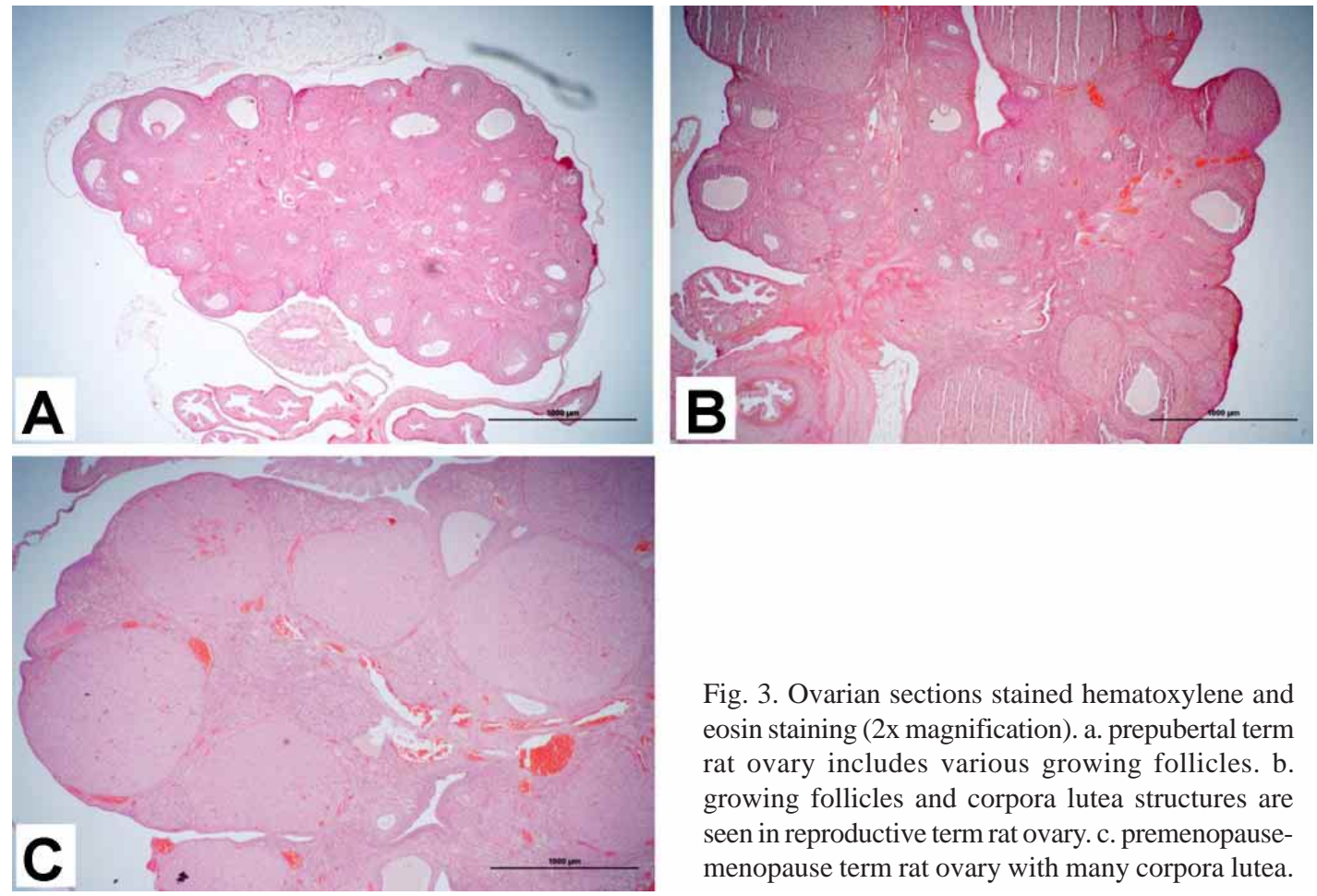

Fig. 3. Ovarian sections stained hematoxylene and eosin staining ( $2 \mathrm{x}$ magnification). a. prepubertal term rat ovary includes various growing follicles. $b$. growing follicles and corpora lutea structures are seen in reproductive term rat ovary. c. premenopausemenopause term rat ovary with many corpora lutea.
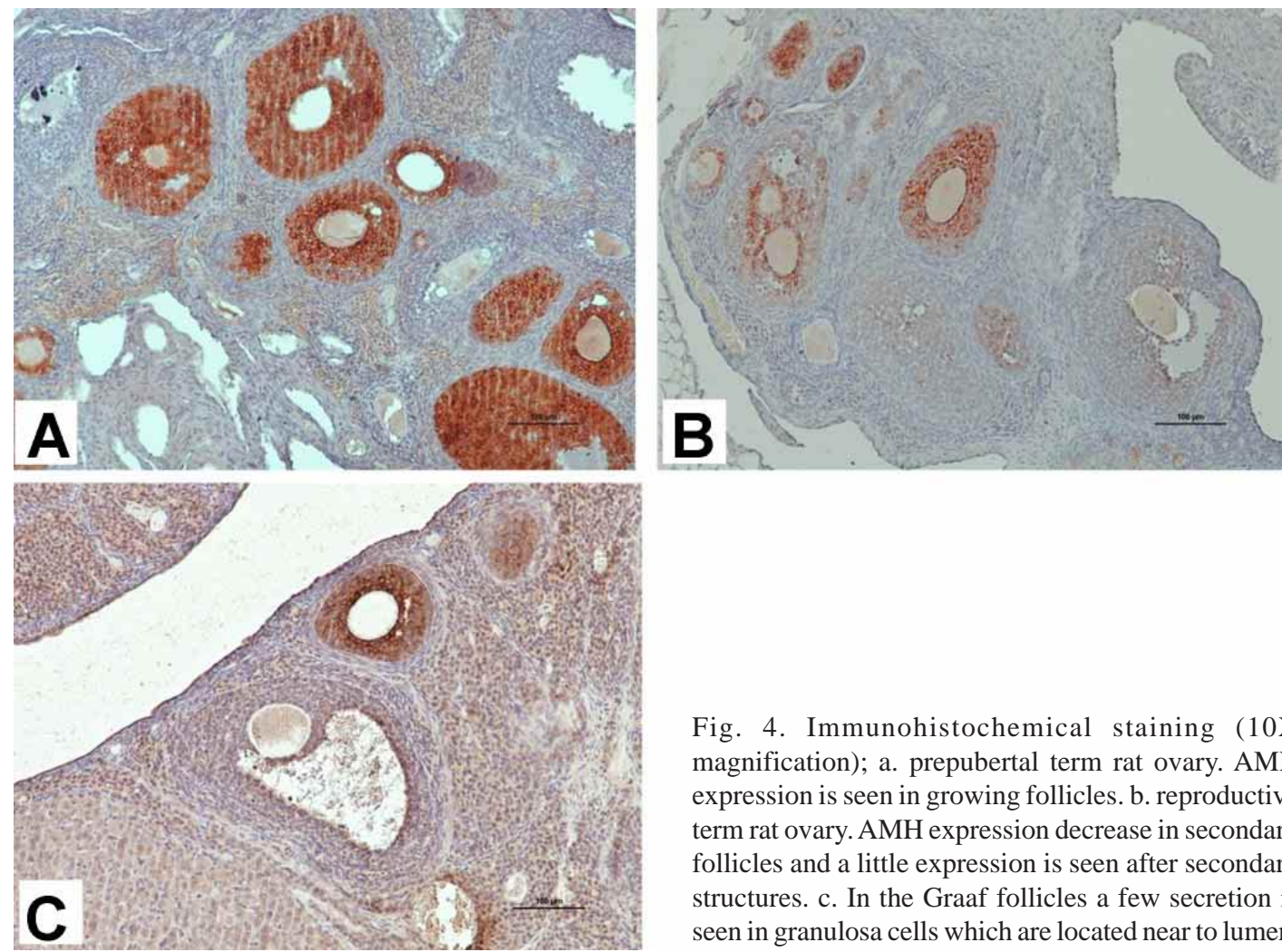

Fig. 4. Immunohistochemical staining (10X magnification); a. prepubertal term rat ovary. AMH expression is seen in growing follicles. b. reproductive term rat ovary. AMH expression decrease in secondary follicles and a little expression is seen after secondary structures. c. In the Graaf follicles a few secretion is seen in granulosa cells which are located near to lumen. 


\section{DISCUSSION}

A portion of the follicles developing in the primordial follicle pool throughout life are destroyed by atresia (McGee \& Hsueh, 2000). Oocyte atresia is observed during prenatal period and reproductive period. Atresia of oocytes is observed in primary, secondary and antral follicle stages. Upon entering menopause, approximately 1000 primordial follicles remain in the ovaries without developing (Oktem \& Oktay, 2008).

It has been reported that there are antral follicles developing in the prepubertal period, covering 2 months, in rats. However, these developing antral follicles were atresied and corpus luteum was not observed, also the amount of corpus luteum increased due to aging and it was difficult to differentiate the histological features of ovaries in senescent rats (Vidal, 2017). In this study, it was observed that onemonth old rats had follicles developing in their ovaries and no corpus luteum structures. The fact that the follicles developing intensively in the prepubertal period and the absence of corpus luteum show that the higher number of follicles may undergo atresia before reaching ovulation. Especially in the ovaries of menopausal period rats, it has been observed that the quantity of corpus luteum cells increased which in turn increased ovarian volume and vascularization. In addition, age related spreading of luteal cell accumulation to ovarian stroma was observed. This particularly indicates the existence of residuary lutein cells resulting from apoptotic and increased number of corpora lutea in individuals during the premenopausal-menopausal period. It was determined that the number of primordial follicles observed at the highest level in the prepubertal period which declined towards the menopause period. It was also determined that the number of developing follicles decreased in relation with the increasing age. Some developing follicles were also found in rats in the premenopause-menopause period. This shows that entering menopause is not only due to the depletion of the ovarian reserve, but rather because of the morphological and physiological reasons such as end of reproductive period and developing follicles undergoing atresia without ovulation.

In women, Anti-Müllerian hormone is secreted from the granulosa cells of developing follicles. Expression of AMH begins with the secretion from single-layer granulosa cells of primary follicles and continues until menopause (Rajpert-De Meyts et al., 1999). The follicles of which AMH expression reaches the highest level are preantral and small diameter antral follicles. AMH secretion is not seen in the mural granulose and cumulus cells of the preovulatory follicles and the follicles undergoing atresia (Salmon et al., 2004). In immunohistochemical studies, it was determined that the expression of AMH was highest in small antral follicles, and a steady decrease in antral follicles larger than $4 \mathrm{~mm}$ was observed (Weenen et al., 2004). In this study, it was observed that AMH release was secreted from primary, preantral, secondary and tertiary follicle cells. In late period secondary and tertiary follicles, only a low number of AMH $(+)$ stained granulosa cells were detected in some of the mural granulosa and cumulus cells. AMH expression was not observed in primordial follicle cells. The number of follicle cells expressing AMH increased as the follicle size increased.

The level of AMH varies in the circulatory system of females. Achieving its first peak level immediately after birth, AMH expression continues until about 9 years of age. The second peak level is observed at the age of 25 , and it gradually decreases until the age of 50-51 which then becomes almost immeasurable in serum at menopause (Fleming et al., 2012). AMH functions as a kind of inhibitory growth factor in the early stages of folliculogenesis in ovaries and inhibits the development of primordial follicle (Durlinger et al., 2002). The amount of AMH levels in circulatory system reflects the total number of underdeveloped granulosa cells located in the two ovarium and the total number of developing follicles (Voorhuis et al., 2010). In this study, the serum AMH levels observed to have no significant correlation with the number of primordial follicles. However, a significant correlation was observed between serum AMH levels and the number of follicles developed in the prepubertal period. First of all, the presence of AMH in serum during the prepubertal period is due to developing follicles in the ovaries. Compared to other period groups, although the number of follicles developing in the prepubertal period is higher, the serum AMH levels are low in this period. The fact that most of the developed follicles undergo atresia before reaching the preantral and antral level is suspected to be the reason behind the detected low AMH concentration in the serum. Thus, the amount of AMH expressed from primary follicles in the ovary may not reach to the amount expressed during the reproductive period. For the same reason, AMH might not be able to suppress FSH sensitivity of all primordial follicles, resulting in the initiation of developing an increased number of follicles. This situation indicates that there is a large number of developing follicles from birth to puberty period as well as a rapid reduction of the follicles in the primordial pool. Studies to be done in individuals before puberty can reveal the exact biological system involved in this process, and it might be possible to develop precautionary steps to ensure higher number of primordial follicles are available at the beginning of puberty period. Thus, detecting the concentration of serum AMH could be used to determine the amount of ovarian reserve in 
the puberty period and to estimate the beginning of the menopause period in the individual. It is observed that there is a small number of follicles in female individuals entering the premenopause-menopause period and that these follicles express Anti-müllerian hormone during the development stage, which explains the reason behind detection of $\mathrm{AMH}$ in the serum. The development of low number primordial follicles but the absence of ovulation in the premenopausemenopause period could be explained by the lack of hormonal stimulation that is involved in establishing a suitable environment for ovulation. In order to understand the oocytehormonal interaction in individuals during the menopause period, molecular studies on biological pathways will be decisive, and the age of menopause could be delayed by using the data of oocyte reserves in an individual.

INHB hormone is thought to play an important role as a physiological hormone in determining the dominant follicle in the follicular phase by creating an endocrine and paracrine effect in the menstrual cycle (Yding et al., 2008). INHB is secreted mostly from preantral and small antral follicles. Therefore, serum INHB levels in the circulation system commonly indicates follicle synthesis. Decrease in the serum INHB levels is the earliest marker of declining follicle numbers in the reproductive period (Welt). In this study, it was observed that INHB hormone was expressed more during the active reproductive period compared to other period groups. In all age groups, a positive correlation was observed between serum INHB and FSH levels. There was a significant correlation between the serum INHB levels and the number of primordial follicles in the prepubertal period. Therefore, serum INHB levels could be interpreted as a marker that displays the number of follicles in the ovarian reserve during the prepubertal period.

In conclusion, $\mathrm{AMH}$ is synthesized from preantral and early antral follicles. In the late period secondary follicles, the amount of expression decreases, whereas in tertiary follicles, a low level of expression occurs. In relation with the age period, $\mathrm{AMH}$ is secreted at higher levels in the ovaries of individuals during reproductive period. In the prepubertal period, AMH might have a protective effect on the ovarian reserve. Considering the prepubertal and premenopausal-menopausal period, the presence of serum $\mathrm{AMH}$ does not fully reflect reproductivity. INHB hormone has a function of inhibiting FSH expression. Individuals in the prepubertal period, the levels of serum INHB can be used to determine the number of follicles in the ovarian reserve. However, it does not fully reflect reproductivity, such as $\mathrm{AMH}$, when the prepubertal and premenopausalmenopausal period is considered. Since AMH and INHB are secreted from developing follicles, their serum concentrations play an important role in the reproductivity of female individuals during all periods. In order to better understand the reproductive endocrinology, large-scale investigations at molecular level on the basis of receptors and biological pathways are required.

\section{ACKNOWLEDGEMENTS}

The study was supported by the Abant Izzet Baysal University Scientific Research Projects Unit (Project no: 2016.08.03.1080)

SÖYLER, G.; BUGDAYCI, G. \& KÜKNER, A. Comparación de la hormona anti-mülleriana relacionada con la edad, los niveles de inhibina-b y la reserva folicular en el ovario de rata. Int. J. Morphol., 39(4):1074-1080, 2021.

RESUMEN: La hormona antimülleriana $(\mathrm{AMH})$ y la inhibina B (INHB) en la estructura de la glicoproteína son miembros de la familia del factor de crecimiento transformante $\beta$ y se expresan en las células de la granulosa desde la pubertad. La AMH es un factor que aumenta la vida útil de los pequeños folículos en desarrollo. Por este motivo, se utiliza frecuentemente para determinar la reserva ovárica y la edad. La inhibina B secretada por las células de la granulosa tiene un rol en la regulación del factor estimulante de (FSH) y en la determinación del diámetro del folículo. Hay pocos estudios sobre el efecto de estas dos hormonas relacionadas con la edad en la histología ovárica en ratas. Se examinaron histológica y bioquímicamente la expresión de AMH e INHB en tejidos ováricos de ratas hembras de diferentes grupos de edad, su relación con la estructura ovárica y la foliculogénesis. Se utilizaron ratas Wistar Albino en el estudio y se formaron 3 grupos. En los ovarios de ratas en el período preestro se realizó el recuento de folículos en secciones de tejido. La expresión de AMH en los folículos se identificó inmunohistoquímicamente. En suero, los niveles de AMH e INHB se evaluaron mediante el método ELISA y su importancia se evaluó estadísticamente. Los resultados del examen con microscopio óptico determinaron que la AMH se expresaba a partir de las células de la granulosa de los folículos en desarrollo. La expresión de INHB durante el período prepuberal y AMH tuvo un efecto protector sobre la reserva ovárica y el número de folículos en desarrollo, respectivamente.

PALABRAS CLAVE: Rata; Edad, Ovario; Hormona Anti-Mülleriana; Inhibina B.

\section{REFERENCES}

Ackland, J. F.; D’Agostino, J.; Ringstrom, S. J.; Hostetler, J. P.; Mann, B. G. \& Schwartz, N. B. Circulating radioimmunoassayable inhibin during periods of transient follicle-stimulating hormone rise: secondary surge and unilateral ovariectomy. Biol. Reprod., 43(2):347-52, 1990.

Cossigny, D. A.; Findlay, J. K. \& Drummond, A. E. The effects of FSH and activin A on follicle development in vitro. Reproduction, 143(2):2219, 2012. 
DePaolo, L. V.; Bicsak, T. A.; Erickson, G. F.; Shimasaki, S. \& Ling, N. Follistatin and activin: a potential intrinsic regulatory system within diverse tissues. Proc. Soc. Exp. Biol. Med., 198(1):500-12, 1991.

Durlinger, A. L. L.; Visser, J. A. \& Themmen, A. P. N. Regulation of ovarian function: the role of anti-Müllerian hormone. Reproduction, 124(5):6019, 2002.

Eppig, J. J. Oocyte control of ovarian follicular development and function in mammals. Reproduction, 122(6):829-38, 2001

Fleming, R.; Kelsey, T. W.; Anderson, R. A.; Wallace, W. H. \& Nelson, S. M. Interpreting human follicular recruitment and antimüllerian hormone concentrations throughout life. Fertil. Steril., 98(5):1097-102, 2012.

Grynnerup, A. G. A.; Lindhard, A. \& Sørensen, S. The role of anti-Müllerian hormone in female fertility and infertility - an overview. Acta Obstet. Gynecol. Scand., 91(11):1252-60, 2012.

Kedem, A.; Yung, Y.; Yerushalmi, G. M.; Haas, J.; Maman, E.; Hanochi, M.; Hemi, R.; Orvieto, R.; Dor, J. \& Hourvitz, A. Anti Müllerian Hormone (AMH) level and expression in mural and cumulus cells in relation to age. J. Ovarian Res., 7:113, 2014.

Knight, P. G. \& Glister, C. TGF-b superfamily members and ovarian follicle development. Reproduction, 132(2):191-206, 2006.

Matsuda, F.; Inoue, N.; Manabe, N. \& Ohkura, S. Follicular Growth and Atresia in Mammalian Ovaries: Regulation by Survival and Death of Granulosa Cells. J. Reprod. Dev., 58(1):44-50, 2012.

McGee, E. A. \& Hsueh, A. J. Initial and cyclic recruitment of ovarian follicles. Endocr. Rev., 21(2):200-14, 2000.

Nelson, S. M.; Anderson, R. A.; Broekmans, F. J.; Raine-Fenning, N.; Fleming, R. \& La Marca, A. Anti-Müllerian hormone: clairvoyance or crystal clear? Hum. Reprod., 27(3):631-6, 2012.

Oktem, O. \& Oktay, K. The ovary: anatomy and function throughout human life. Ann. N. Y. Acad. Sci., 1127(1):1-9, 2008.

Rajpert-De Meyts, E.; Jørgensen, N.; Graem, N.; Müller, J.; Cate, R. L. \& Skakkebaek, N. E. Expression of anti-Müllerian hormone during normal and pathological gonadal development: association with differentiation of Sertoli and granulosa cells. J. Clin. Endocrinol. Metab., 84(10):3836-44, 1999.

Salmon, N. A.; Handyside, A. H. \& Joyce, I. M. Oocyte regulation of antiMüllerian hormone expression in granulosa cells during ovarian follicle development in mice. Dev. Biol., 266(1):201-8, 2004.

Vidal, J. D. The impact of age on the female reproductive system. Toxicol. Pathol., 45(1):206-15, 2017.

Visser, J. A. \& Themmen, A. P. N. Anti-Müllerian hormone and folliculogenesis. Mol. Cell. Endocrinol., 234(1-2):81-6, 2005.

Visser, J. A.; Durlinger, A. L. L.; Peters, I. J. J.; van den Heuvel, E. R.; Rose, U. M.; Kramer, P.; de Jong, F. H. \& Themmen, A. P. N. Increased oocyte degeneration and follicular atresia during the estrous cycle in anti-müllerian hormone null mice. Endocrinology, 148(5):2301-8, 2007.

Voorhuis, M.; Onland-Moret, N. C.; van der Schouw, Y. T.; Fauser, B. C. J. M. \& Broekmans, F. J. Human studies on genetics of the age at natural menopause: a systematic review. Hum. Reprod. Update, 16(4):364-77, 2010.

Weenen, C.; Laven, J. S. E.; Von Bergh, A. R. M.; Cranfield, M.; Groome, N. P.; Visser, J. A.; Kramer, P.; Fauser, B. C. J. M. \& Themmen, A. P. N. Anti-Müllerian hormone expression pattern in the human ovary: potential implications for initial and cyclic follicle recruitment. Mol. Hum. Reprod., 10(2):77-83, 2004.

Welt, C. K. Regulation and function of inhibins in the normal menstrual cycle. Semin. Reprod. Med., 22(3):187-93, 2004.

Welt, C. K.; McNicholl, D. J.; Taylor, A. E. \& Hall, J. E. Female reproductive aging is marked by decreased secretion of dimeric inhibin. J. Clin. Endocrinol. Metab., 84(1):105-11, 1999.

Woodruff, T. K. \& Mather, J. P. Inhibin, activin and the female reproductive axis. Аnnu. Rev. Physiol., 57(1):219-44, 1995.

Yding, A. C.; Rosendahl, M. \& Byskov, A. G. Concentration of antiMüllerian hormone and inhibin-B in relation to steroids and age in follicular fluid from small antral human follicles. J. Clin. Endocrinol. Metab., 93(6):2344-9, 2008.
Corresponding author:

Professor Aysel Kükner MD.

Near East University

Medicine Faculty

Histology and Embryology Department

Nicosia 99138

CYPRUS

Email: akukner@hotmail.com

Received: $16-11-2020$

Accepted: 22-05-2021 